\title{
Evolusi Metabolisme Biotek Anaerob
}

Gede H. Cahyana ${ }^{1}$

\begin{abstract}
Abstrak
Rentang sejarah bioteknologi anaerob sangat panjang. Berbagai tipe raktor telah dibuat dan banyak yang gagal, tinggal namanya saja. Namun, banyak juga yang berhasil dan menjadi cikal perkembangan biotek anaerob selanjutnya. Awalnya, bioreaktor ini dianggap buruk kinerjanya. Lalu, pada awal tahun 1970-an, mulai ditemukan teknologi yang membuat proses anaerob mampu ditandingkan dengan proses aerob. Malah laju aplikasinya melesat di banyak negara. Sejumlah keunggulannya adalah hemat lahan, rendah timbulan sludge, dan penghasil energi listrik.
\end{abstract}

Kata kunci: bioteknologi, anaerob, kelirumologi, swahenti

\section{Kilas Balik}

Sebelum tiba pada era reaktor modern, telah panjang sejarah perkembangan proses anaerob. Oleh sebab itu, ada banyak data yang berbeda utamanya soal tahun penemuan atau pembuatan unit pengolah yang ditulis di jurnal, paper dan/atau buku. Juga, bisa saja ada negara yang sudah menerapkannya, tetapi tak terpantau, tak ditulis atau tak dipublikasikan. Karenanya, kapan, di mana dan siapa yang pertama kali menerapkannya masih bisa diperdebatkan. Artinya, kronologis catatan itu, termasuk yang direkam di artikel ini bisa berubah setiap saat mengikuti temuan baru.

Historisnya, bioteknologi (singkat: biotek) pengolahan air limbah secara anaerob berkembang lebih awal daripada proses aerob. Namun demikian, di banyak negara termasuk Indonesia, justru proses ini jarang diterapkan di industri maupun domestik komunal. Indikatornya, jumlah unitnya sangat sedikit dibandingkan dengan proses aerob. Bahkan ada kesan, banyak yang "alergi" terhadap proses yang sesungguhnya potensial ini. Lalu, siapa yang salah? Barangkali sejarahlah (atau si pembuat sejarah, para desainer) yang salah. Sebab, selama ini ia hanya didesain untuk mengolah lumpur (sludge) dari klarifir primer dan sekunder proses aerob dan limbah ternak (manure).

\footnotetext{
${ }^{1}$ Dosen Jurusan Teknik Lingkungan Universitas Kebangsaan, Bandung.
} 
Lepas dari "dosa sejarah" itu, proses metanogenesis sudah lama diketahui. Tahun 1776, fisikawan Italia Alessandro Volta, telah mengidentifikasi metana dari busukan sedimen danau (Nyns, 1986; Leiderberg, 1992). Selain itu, semua habitat archae atau metanogen adalah sumbernya. Mulai dari sludge digester, perut hewan, rumen, sanitary landfill, tangki septik, cubluk, sawah, genangan hingga ke sumber air panas dan geotermal. Gas yang tak larut di dalam air (insoluble) ini, atom karbonnya hanya satu dan dinamai pula gas rawa (marsh gas) karena sering muncul di rawa-rawa. Yang terpenting dari gas ini adalah potensi energinya yang tidak kalah dengan energi surya ataupun mikrohidro dalam hal penyediaan energi murah.

Meski begitu, hampir seabad kemudian proses ini baru dipraktikkan untuk mengolah lumpur dan air limbah. Aplikasinya yang relatif lama itu diawali oleh Mouras automatic scaverager pada 1860 di Prancis. Reaktor yang didesain oleh Louis H. Mouras ini, tulis Wang (1994), adalah digester (pencerna) lumpur pertama di dunia. Lalu pada 1895, Donald Cameron membuat tangki septik pengolah lumpur di Exeter, Inggris. Dialah identifikator pertama metana dari unit pengolah limbah dan energinya itu digunakan untuk penerangan di sekitar instalasinya.

Seiring dengan perjalanan waktu, implementasi tangki septik tadi kian luas dan mampu mengurangi masalah polusi pada saat itu, terutama dari air limbah dan sludge domestik. Tapi karena berupa desain awal atau prototipe maka muncul juga masalah yang disebabkan oleh gas yang dihasilkannya. Pasalnya, gas yang kemudian disebut biogas itu ikut mengapungkan padatan tersuspensi atau bioflok bakteri yang telah dan akan mengendap sehingga melayang di muka air. Juga terbentuk busa kehitaman, berisi material tak terolah (indigestible). Bahkan endapan di dasar tangki pun ikut melayang sehingga merusak mutu efluennya. Inilah sebabnya mengapa para desainer berupaya keras mencarikan solusinya.

Empat tahun kemudian, pada 1899, Harry Clark punya ide, yakni memisahkan tangki sedimentasi dengan tangki digester. Hasilnya, kinerja proses meningkat karena mampu mereduksi resuspensi lumpur dan bioflok. Selanjutnya pada 1904 di Hampton Inggris dibangun 'dual-purpose tank', yaitu separasi tangki sedimentasi dengan tangki pengolah 
lumpur (digester). Pada Travis hydrolytic tank ini, air limbah masuk ke hydrolysing chamber yang berperan sebagai digester. Adapun padatan tersuspensinya (suspended solid) diendapkan di saluran atau kanal (channel). Kedua ruang itu dipisahkan oleh sekat (baffle).

Pada tahun itu juga, Dr. Karl Imhoff dari Jerman membuat 'dual-purpose two-story tank' yakni pemisahan ruang sedimentasi dengan ruang hidrolisis (hydrolysing) atau digester. Tangki yang dipatenkan dengan nama Imhoff tank ini, juga dianggap pionir separasi tangki sedimentasi dengan digester. Dengan hanya satu unit reaktor, ia punya dua ruang (bikamar) yang fungsinya berbeda. Karena jasanya itulah, nama penemunya dijadikan nama jalan di Bandung, Jalan Imhoff Tank di dekat instalasinya yang dibangun pada zaman penjajahan Belanda. Kini rangkanya masih bisa dilihat di dekat jalan itu, berbaur dengan pemukiman.

Semua unit pengolah yang dipaparkan di atas terfokus pada pengolahan lumpur atau padatan tersuspensi dari limbah domestik. Sebab, hingga ujung abad ke-19 itu memang belum banyak ada industri sehingga kasus polusi air lebih banyak disebabkan oleh air limbah domestik. Selain itu, juga karena tingkat polusinya tidak separah sekarang sehingga masih tertangani dengan teknologi klasik. Begitu pun pengolahan limbah kotoran ternak dengan digester, idenya dipioniri oleh Ducellier dan Isman dari Prancis pada tahun 1941 .

Adapun yang dianggap pionir dalam bidang pengolahan air limbah domestik (jadi bukan padatannya) adalah Scott-Moncrieff di Inggris pada 1891. Tangki pengolahnya terdiri atas dua kompartemen, bagian atas dan bagian bawah. Segmen atas diisi batu sedangkan bagian bawahnya dibiarkan kosong. Aliran airnya dari bawah ke atas, melewati sela-sela batu yang sekarang dikenal dengan porositas reaktor. Boleh jadi, inilah ide awal dari filter anaerobik yang dibuat oleh Young \& McCarty delapan puluh tahun kemudian, awal 1970-an.

Tipe reaktor selanjutnya dibuat oleh Winslow dan Phelps pada 1910. Pada reaktor ini telah ada sentuhan inovasi dari pendahulunya berupa bentuk kerucut. Tangki kerucut 
yang dinamai "biolytic" ini, digunakan untuk mengolah air limbah domestik yang dialirkan dari bawah ke atas (upflow), melewati lapisan atau selimut (blanket) lumpur. Dengan waktu tinggal (residence time) yang singkat, hanya 8,5 jam, penyisihan padatannya menyamai tangki septik. Seperti halnya filter anaerob buatan Young \& McCarty, dapatkah reaktor ini disebut sebagai ide awal dari UASB (upflow anaerobic sludge blanket) yang dikembangkan Lettinga dkk pada 1970-an di Belanda?

Selanjutnya, di sektor air limbah industri, menurut Henze, et.al (1996), IPAL pertama di dunia dibuat tahun 1929 di Slagelse, Denmark. Reaktor klasik dengan proses Anaerobic Contact ini digunakan untuk mengolah air limbah pabrik ragi (Danish Destillers). Perkembangan selanjutnya, ia digunakan juga untuk air limbah pabrik gula dan minuman. Di Kopenhagen misalnya, pada 1970 dibangun Kontak Anaerob (Contact Anaerobic Reactor) yang unit sedimentasinya difasilitasi dengan lamella atau lembar pengendap. Ketika bukunya terbit tahun 1996, IPAL itu masih berfungsi dengan baik.

Sampai 1950, sejarah perkembangan dan inovasi reaktor anaerob kian banyak saja yang semuanya demi perbaikan proses dan mutu efluennya. Juga mulai dikenal dasar-dasar proses, teknik kendali, desain tangki dan peralatannya. Karenanya, setelah yakin pada kelebihan digester bikamar itu dirancanglah digester laju tinggi (high rate) yang diterapkan secara luas. Tapi sayangnya, seperti disebut di atas, digester cepat itu hanya digunakan untuk mengolah lumpur. Tak diperluas untuk mengolah air limbah sehingga menjadi sejarah kelam bagi perkembangannya di kemudian hari. Baru pada pasca 1950, lewat riset di sejumlah digester anaerob, karakteristik biokimia dan mikrobiologinya kian dipahami, di antaranya kondisi lingkungan (temperatur, $\mathrm{pH}$ ) dan biodegradabilitas (keterolahan secara biologi) zat organik.

Apa yang dibahas di atas adalah rentetan evolusi reaktor klasik konvensional yang kecepatan olahnya masih rendah atau digester lambat. Karenanya, upaya perbaikan pun terus dilakukan. Schroepfer, misalnya, pada tahun 1955 meresirkulasi endapan lumpur (biomassa aktif) yang ada di unit sedimentasi. Kemudian Stander pada 1966 membuat Clarigester, dilengkapi dengan settler agar biomassa aktifnya tidak hanyut. Akhirnya tahun 1970 dan sesudahnya, kesulitan operasi teratasi setelah hadir inovasi proses 
anaerob laju tinggi. Reaktor inovatif itu adalah Anaerobic Filter (Young, McCarty, 1969), UASB (Lettinga, 1979), Fluidized Bed (Jerish, 1982), Expanded Bed (Jewel, 1979, Switzenbaum, 1980, Speece, 1983), Baffled Reactor (Bachmann et al., 1985), dan Anaerobic Rotating Biological Contactor (Friedman, 1980).

Kecuali UASB, semua reaktor tersebut menggunakan media (carrier) sebagai tempat melekat bakteri. Jadi, berupa reaktor pertumbuhan lekat (attached growth). Khusus Anaerobic Filter aliran ke atas (upflow), kekurangannya adalah ada peluang penyumbatan (clogged) pada ruang antarmedia (porositas reaktor) dan endapan lumpur di dasarnya. Melihat hal itu, muncullah inovasi anyar. Genung (1985) memodifikasinya menjadi reaktor bastar atau hibrid yang bagian atasnya untuk pertumbuhan lekat sedangkan ruang di bawahnya untuk pertumbuhan tersuspensi.

Yang unggul dan banyak diterapkan sekarang di industri adalah reaktor inovatif itu. Ia juga dinamai reaktor nir-konvensional atau modern karena merujuk pada kecepatan olahnya yang sangat tinggi. Bukan hanya itu, reaktor modern ini pun mampu mengolah air limbah yang mengandung zat toksik atau senyawa recalcitrant seperti chlorinated aliphates, chlorinated aromates, nitroaromates dan zat xenobiotik lainnya. Sebab itulah ia disebut sebagai teknologi yang terjamin (a proven technology), menjadi tumpuan harapan pada basis pendekatan ujung pipa (the end of pipe), sebagai pelengkap pendekatan teknologi bersih (clean technology). Kedua pendekatan itu, mau tak mau, mesti diakomodasi oleh kalangan industri.

\section{Keunggulan Anaerob}

Dibandingkan dengan proses aerob, ada sejumlah kelebihan atau manfaat dari proses anerob dalam pengolahan air limbah. Speece (1996) berhasil mengompilasinya menjadi beberapa poin.

(1). Stabilitas proses.

Meskipun kondisi lingkungannya bervariasi, kalau proses mampu menghasilkan swahenti biomassa maka akan dicapai proses yang stabil. Yang bisa melakukan itu adalah reaktor anaerob modern dengan biomassa berujud ganular (biobutir) dan slime (fixed film). Selain itu, mesti dipenuhi juga kebutuhan mineral runutnya (trace). 
(2). Reduksi volume lumpur dan luas lahan

Salah satu masalah krusial dalam proses aerob adalah volume lumpurnya yang sangat besar. Untuk membuangnya perlu biaya dan lahan. Sedangkan lumpur proses anaerob sedikit sekali, biayanya hanya $10 \%$ dari biaya penanganan lumpur proses aerob. Dengan demikian, hemat biaya dan lahan.

(3). Beban organiknya besar

Kecepatan pembebanan organik yang mampu dicapai proses anaerob adalah 3,2 - 32 $\mathrm{kg} / \mathrm{m} 3$.hari. Sedangkan yang aerob hanya $0,5-3,2 \mathrm{~kg} / \mathrm{m} 3$.hari.

(4). Potensi energi.

Kalau proses aerob membutuhkan energi untuk aerasinya, proses anerob justru menghasilkan energi. Per $1.000 \mathrm{~kg}$ COD yang diubah menjadi metana dihasilkan tak kurang dari 12 juta BTU. Dan ini potensial buat energi listrik, minimal di instalasinya.

\section{Metabolisme Anaerob}

Sesuai dengan namanya, pada proses anaerob $(\mathrm{an}=\mathrm{tidak}$, aerob $=$ udara atau oksigen $)$ tidak ada oksigen yang terlibat atau dikonsumsi oleh mikroba sehingga tidak ada reduksi zat organik. Namun penyisihannya dapat terjadi jika zat organik telah dikonversi menjadi metana, yang lepas ke udara luar. Inilah kunci sukses proses anaerob.

Ada sejumlah pola, alur (pathway) degradasi zat organik, mulai dari yang sederhana sampai dengan yang kompleks, melibatkan banyak grup atau kelompok bakteri. Menurut Hobson dan Wallace (1982) dan Wang K, (1994), ada tiga tahap degradasi anaerob zat organik terlarut maupun tersuspensi, yaitu reaksi enzimatis ekstraseluler, asidogenesis dan aseto-metanogenesis. Namun menurut Gujer dan Zehnder (1982), ada enam alur pembentukan metana seperti diperlihatkan pada Gambar 1 (Wang K, 1994). 


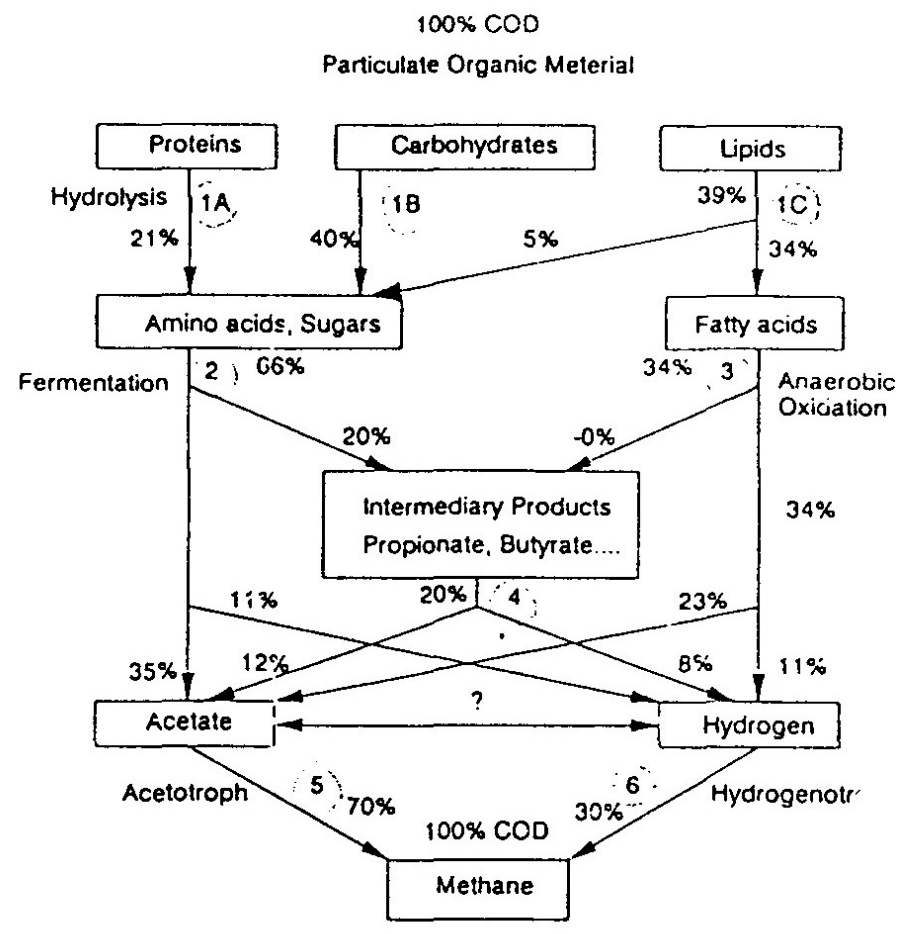

Gambar 1. Degradasi Anaerobik Senyawa Kompleks (Wang K, 1994).

\section{a. Reaksi enzimatis ekstraseluler}

Zat organik tersuspensi (insoluble) atau terlarut bermolekul besar, tak dapat langsung dimetabolisme oleh bakteri karena tidak bisa menembus membran sel sehingga harus dilarutkan dulu (solubilisasi, likuifaksi) dan ukurannya (berat molekulnya) diperkecil. Penanggung jawab pelarutan dan reduksi ukuran itu ialah reaksi hidrolisis yang dikatalisis enzim ekstraseluler hasil ekskresi bakteri. Inilah yang membantu transformasi atau hidrolisis partikulat dan senyawa polimer (karbohidrat, protein, lemak) menjadi monomer sehingga dapat ditransportasikan ke dalam sel dan dimetabolisme sebagai sumber energi dan karbon. Namun karena tahap ini tidak dihasilkan metana maka belum ada reduksi COD.

Berdasarkan cara atau jenis aksi exo-enzyme tersebut, bakteri hidrolitis yang diisolasi dari rumen dan sludge digester dikelompokkan menjadi cellylytic, proteolytic dan lipolytic. Khusus untuk digester yang dominan mengandung insoluble substrate seperti kotoran sapi, babi dan limbah selulosa, maka tahap pelarutan atau solubilisasi ini 
menjadi penentu proses keseluruhan (rate limiting step). Pelarutan zat tersebut bergantung pada komposisi kimia (biodegradabilitas), sifat fisika (ukuran dan porositas partikel) dan faktor lingkungan: temperatur dan $\mathrm{pH}$.

\section{b. Tahap asidogenesis}

Monomer yang dihasilkan pada tahap hidrolisis seperti asam lemak rantai panjang, asam amino, gula dan alkohol, selanjutnya dimetabolisme intraseluler oleh bakteri hidrolitis dan non-hidrolitis yang digunakan sebagai sumber karbon dan energi. Selain hasilnya berupa asam asetat, propionat, butirat dan $\mathrm{H} 2 / \mathrm{CO} 2$, juga sejumlah kecil asam format, laktat, valerat, metanol, etanol, butanediol atau aseton. Karena asam lemak volatil adalah hasil utama tahap ini, maka golongan bakterinya disebut acidifying atau acidproducing bacteria atau acidogenic bacteria atau acidogens yang tahan pada $\mathrm{pH}$ rendah $(\mathrm{pH}<5)$. Pada tahap ini dibutuhkan banyak alkalinitas untuk mengimbangi produksi CO2 dan asam-asam volatil. Jika tidak cukup, maka eksistensi metanogen terancam, termasuk kinerja reaktornya.

\section{c. Tahap aseto-metanogenesis}

Sebagai tahap terpenting pada proses anaerob, metanogen prokaryote bertugas mengonversi substrat atau senyawa antara (intermediate) di atas menjadi $\mathrm{CH} 4$ dan $\mathrm{CO} 2$. Substrat yang dapat diubah menjadi metana tersebut, menurut Brock T. D (1997), dibagi menjadi tiga kelas.

Kelas I (pengguna $\mathrm{CO} 2$ ) terdiri atas $\mathrm{CO} 2$, format dan $\mathrm{CO}$ dengan donor elektron dari H2, alkohol atau piruvat. Kelas ini juga disebut hidrogenotrofik atau hidrogenofilik (pengguna hidrogen). Metanogennya bersifat autotrof (CO2 sebagai sumber karbon dan aseptor elektron). Kelas II ialah pengguna grup metil $\left(\mathrm{CH}_{3}\right)$ seperti metanol, metilamin, dimetilamin, trimetilamin, metilmerkaptan dan dimetilsulfida. Kelas III (pengguna asetat atau asetotrofik) terdiri atas dua genus archae yaitu Methanosarcina dan Methanosaeta (Methanothrix). Kelas inilah sumber utama (prekursor) metana karena tak kurang dari $70 \%$ total metana berasal dari asam asetat sedangkan sisanya dari $\mathrm{H} 2 / \mathrm{CO} 2$. Atau secara total, lebih dari $90 \%$ zat organik diubah menjadi $\mathrm{CH} 4$ dan sisanya untuk sintesis biomassa. 
Pada metabolisme anaerob, ada hubungan sinergis antara penghasil hidrogen dengan pengguna hidrogen. Perubahan pada kondisi tekanan parsial hidrogen akan berpengaruh pada produk akhir fase asidogenesis. Jika ada kenaikan tekanan parsial hidrogen maka oksidasi hidrogen menjadi dominan daripada degradasi asetat sehingga konsentrasi asetat meningkat. Degradasi alkohol pun dapat terganggu oleh tekanan hidrogen yang tinggi.

Jadi, meskipun hidrogen yang dihasilkan sedikit tetapi merupakan senyawa antara (intermediate) yang berperan penting pada metabolime anaerob, sehingga disarankan tekanan parsial $\mathrm{H} 2$ di bawah 0,0001 atm agar proses anaerob berjalan stabil dan kinerjanya baik.

\section{Kelirumologi}

Pada "Kilas Balik" di atas telah dipaparkan evolusi reaktor anaerob dan mengapa perkembangannya demikian lamban sehingga popularitasnya dikalahkan oleh proses aerob. Dari paparan itu dapat diketahui bahwa dominasi unit pengolah ketika itu adalah reaktor pengolah lumpur saja (digester). Dengan demikian, kalau dicari biang keladi dari stagnasi proses ini, ia tak lain dari unit pengolah lumpur anaerob (anaerobic sludge digester). Inilah yang dianggap memunculkan pandangan keliru terhadap keandalan proses anaerob dalam mengolah air limbah (wastewater).

Sejumlah parameter keliru yang biasanya dijadikan tolok-ukur atau tolok-banding proses ini dengan proses aerob, dibahas berikut ini.

(1). Efisiensi.

Hingga 1970-an, selain limbah ternak, proses anerob pun banyak diterapkan untuk mengolah lumpur IPAL aerob yang menggunakan lumpur aktif (activated sludge) dan modifikasinya. Sebab itulah istilah yang digunakan digestion (pencernaan) dan bukan treatment (pengolahan). Sebagai reaktor klasik, tentu saja kemampuan digester sangat rendah dalam mengolah limbah sehingga kalau efisiensinya dibandingkan dengan IPAL aerob, pasti kalah. Perbandingan seperti ini, menurut pakar pengolahan air limbah Henze et.al., (1995), sungguh tidak tepat. Digester anaerob tidak sama dengan 
pengolahan air limbah anaerob. Karena itu, menjadi tidak comparable jika dibandingkan dengan pengolahan air limbah secara aerob.

Pada pengolahan air limbah, lanjut pakar dari Denmark itu, sebagian besar zat organik dalam keadaan terlarut (dissolved organic) dan waktu tinggal hidrolisnya (hydraulic retention time) sangat jauh berbeda (uncoupled) dengan umur lumpurnya (sludge age). Sedangkan pada digester lumpur, baik yang prosesnya aerob maupun anaerob, didominasi oleh zat organik berupa suspensi bakteri dan waktu tinggal hidrolisnya sama dengan umur lumpur. Maka, ia pun dianggap tidak efisien karena lumpur memang lebih sulit diolah daripada zat organik terlarut. Dari sinilah kesan itu muncul bahwa proses anaerob sangat lamban dalam mendegradasi pencemar organik jika dibandingkan dengan proses pengolahan air limbah aerob.

\section{(2). Stabilitas}

Selain masalah mikrobiokimia, ketakstabilan digester anaerob juga banyak terjadi lantaran salah mendesain reaktornya. Misalnya, terjadi banyak ruang nirguna (dead space) di dalam reaktor. Atau karena kurang pengadukan sehingga terjadi arus pendek (short circuiting). Akibatnya, belum sempurna air limbah diolah sesuai dengan waktu tinggal hidrolis yang didesain, sudah langsung menuju outlet (titik keluar).

Selain itu, juga karena hingga akhir 1960-an, karakteristik bakteri pengendali prosesnya belum banyak terungkap. Metanogen, bakteri yang berperan kunci pada proses itu ternyata sangat sensitif terhadap perubahan kondisi lingkungan: temperatur dan $\mathrm{pH}$. Inilah sebabnya kenapa archae, nama yang lebih tepat untuk metanogen, menjadi terganggu pada temperatur kurang dari $20^{\circ} \mathrm{C}$ dan $\mathrm{pH}$ kurang dari 6,0 atau jika fluktuasinya terlalu lebar. Pandangan keliru juga terjadi karena, menurut Speece, tidak paham prinsip dasar proses atau tidak benar desain dan/atau operasinya. Dari fakta yang dikumpulkannya, reaktor konvensional hasil observasinya banyak yang salah desain sehingga laju atau kecepatannya rendah.

Juga banyak yang keliru membandingkan efisiensi digester anaerob pengolah lumpur dengan reaktor pengolah air limbah aerob. Yang disebut kedua adalah pengolah zat organik terlarut di dalam air limbah. Sedangkan digester anaerob adalah pengolah 
lumpur dari proses aerob dan yang berasal dari klarifir pertama. Memang lebih sulit daripada mengolah zat organik terlarut. Inilah cikal-bakal, mengapa proses anaerob dikatakan proses yang tak efisien. Padahal, digester aerob pun kurang efisien jika dibandingkan dengan pengolahan air limbah aerob. Sesungguhnya, proses anaerob dapat didesain untuk mengolah zat organik terlarut secepat atau bahkan lebih cepat daripada proses aerob, dengan KPO (kecepatan pembebanan organik, organic loading rate) tinggi.

Kekeliruan selanjutnya berkaitan dengan termodinamika proses. Perolehan energi oleh mikroba anaerob sangat sedikit dari reduksi zat organiknya. Makanya muncul salah tafsir, bahwa proses ini rendah laju penyisihannya. Mikroba aerob memang mampu mendapatkan energi yang lebih banyak pada zat yang sama daripada yang anaerob. Dari gula misalnya, yang aerob mampu mendapatkan energi 14 kali lebih banyak daripada yang anaerob. Terasa, mikroba anaerob kurang efisien dibandingkan yang aerob.

Tapi sebenarnya, ini tidak berdampak pada kinetika pengolahannya. Dari sisi pengolahan, ada dua akibat, yaitu mikroba aerob menghasilkan lebih banyak lumpur per satuan zat yang terolah. Lantas, energi yang tidak diperoleh mikroba anaerob, hasilnya pada pembentukan metana. Karena kerapkali lumpur menimbulkan masalah maka jumlahnya yang rendah adalah keuntungan proses anaerob, selain sebagai sumber energi murah.

\section{Penutup}

Biotek anaerob dimulai dari reaktor yang tidak diminati teknologinya. Namun, dalam perubahan zaman, justru menjadi reaktor yang menjanjikan. Ini didukung lagi oleh reaktor semacam UASB, filter anaerobic dan hybrid. Dalam reaktor tersebut, banyak dijumpai keunggulannya dibandingkan proses aerob. Kuncinya adalah publikasi dengan cara menyebarluaskan teknologinya. * 


\section{Daftar Pustaka}

1. Droste, Ronald. L (1997). Theory and Practice of Water and Wastewater Treatment. John Wiley \& Sons, USA

2. Henze, et.al (1995). Wastewater Treatment, Springer-Verlag Berlin, Germany.

3. Metcalf, (2003). Wastewater Engineering: Treatment and Reuse, $4^{\text {rth }}$ ed., McGraw Hill, Inc. USA.

4. Speece R.E. (1996). Anaerobic Biotechnology for Industrial Wastewater. Archae Press, Vanderbilt University, England.

5. Wang K. (1994). Integrated Anaerobic-Aerobic Treatment of Sewage. Ph.D Thesis, Wageningen Agricultural University, The Netherlands.

Dipublikasikan di Jurnal Sosioteknologi Terapan Volume IV, hlm. 99-109.

Bulan April 2005, ISBN 979-97637-5-4 